\title{
An integrated community engagement initiative in the rural town of Darling, South Africa
}

\author{
Ruth M Albertyn*, Marietjie J Botha, M Elsabé van der Merwe, \\ Anneri Le Roux, Ilse-Marie Coetzee
}

\begin{abstract}
OPSOMMING
Gemeenskapsinteraksie speel ' $n$ toenemende belangrike rol in ' $n$ samelewing wat verantwoordbaarheid vereis. Universiteite moet ' $\mathrm{n}$ rol speel om ' $n$ verskil te maak binne hulle onmiddellike omgewing en in die breër samelewing. Gemeenskapsinteraksie is ' $n$ manier om die missie van universiteite rakende sosiale geregtigheid en relevansie uit te bou. Die drievoudige rolle van leer, navorsing en gemeenskapsinteraksie plaas druk op akademici binne die akademiese omgewing. Die gemeenskapsinteraksie rol word dikwels afgeskeep aangesien dit die minste erken word binne die akademiese milieu. Indien die gemeenskapsinteraksie rol geïntegreer word met die verskillende kundighede van Boyer (1997) deur sistematiese beplanning, kan die missie van die universiteite uitgebou word en die akademici sal in hul rolverpligtinge slaag.
\end{abstract}

Die artikel fokus op 'n gemeenskapsinteraksie inisiatief as ' $n$ geïntegreerde kundigheidsaktiwiteit toegepas binne ' $n$ departement by ' $n$ hoëronderwys instelling. Die proses van gemeenskapsinteraksie binne die vakrigting volwassene-onderwys word beskryf: eerstens die doelwitte met die gemeenskapsinteraksie inisiatief; tweedens die navorsingsprojekte geïmplementeer deur nagraadse studente binne landelike gemeenskappe as voorbeelde van gemeenskapsinteraksie inisiatiewe; en laastens die lesse geleer deur die gemeenskapsinteraksie inisiatiewe.

Die Development and Advancement of Rural Entrepreneurship (DARE) program is in 1999 gestig en fokus op die opleiding van entrepreneurs deur verskeie projekte in landelike gebiede. Dit was belangrik om te verseker dat die projekte die geïdentifiseerde behoeftes van ' $n$ gemeenskap aanspreek op 'n kundige manier wat wetenskaplikheid, verantwoordbaarheid en relevansie sal verseker. Darling Fokus, 'n gemeenskapsgebaseerde organisasie wat verskeie dienste aanbied, het die Departement Verbruikerswetenskap genader om met hulle opleidingsbehoeftes te help. Darling is 'n landelike gemeenskap wat $65 \mathrm{~km}$ van Kaapstad geleë is waar die hoof bron van inkomste van seisoenale plaaswerk afkomstig is.

Voor- en nagraadse studente is by projekte in Darling betrokke. Die behoefte vir 'n studie om die moontlikheid van entrepreneurskapsontwikkeling deur toerisme te ondersoek, het ontstaan as gevolg van die probleem van onvolhoubare betrokkenheid deur projekdeelnemers sodra die fasiliteerder onttrek.
In die studie is die toeris se behoeftes geïdentifiseer. Opleiding van gemeenskapsdeelnemers is toegespits op die behoefte van toeriste om kwaliteit produkte uit die omgewing met ' $n$ kultuur of natuur tema te bekom. Darling Fokus Sentrum word aanbeveel as ' $n$ ideale omgewing vir hierdie opleiding.

Alle navorsingsresultate is aan Darling Fokus gerapporteer. Daarna is programme aangebied by die Sentrum. Ten spyte van die opleiding aangebied, het gemeenskapslede nie eienaarskap geneem nie en het die bywoningsyfer by opleiding laag gebly. Die vraag het ontstaan waarom gemeenskapslede nie in die aktiwiteite deur die Sentrum aangebied, belanggestel het nie. ' $n$ Moontlike verduideliking is dat die gemeenskap se behoeftes en verwagtinge nie aangespreek word nie. Die doel met die volgende studie was om te bepaal of die dienste, aktiwiteite en programme aangebied deur die Sentrum die behoeftes en verwagtinge van die Darling gemeenskap aanspreek of nie.

'n Geïntegreerde benadering tot die rol van gemeenskapsinteraksie hou voordele in vir die leerervaring van die student. Deur die navorsingsproses neem studente aktief deel aan die leerproses terwyl hulle betrokke is by die gemeenskap. Hulle leer so ook maatskaplike verantwoordbaarheid aan. Die ontwikkeling van nougesette wetenskaplikheid en kundigheid op die nagraadse vlak is verseker deur die fasilitering- en kritiese refleksie prosesse met die studieleier en verantwoordbaarheid teenoor die gemeenskap waar die navorsing plaasgevind het. Die wedersydse gunstige vennootskap is van uiterste belang by gemeenskapsinteraksie. Die langtermyn verbintenis van die Departement oor jare met voor- en nagraadse studente se betrokkenheid het daartoe bygedra. Inligting uit die navorsingsbevindinge het Darling Fokus gehelp met hulle strategiese beplanning. Navorsing in die gemeenskap het die voordeel dat dit bydra tot die missie van die Universiteit om meer relevant in die samelewing te wees.

- Dr RM Albertyn*

Centre for Higher and Adult Education

Department of Curriculum Studies

University of Stellenbosch

Tel: $+27(0) 218082276$

Fax: +27(0)218082270

E-mail:rma@sun.ac.za

* Corresponding author 


- Mrs MJ Botha
Programme manager
Capacity building at the Unit for Religion and
Development Research
University of Stellenbosch
- Mrs ME van der Merwe
Lecturer at the former Department of Consumer
Science
University of Stellenbosch
- Ms A le Roux
Master's student at the former Department of
Consumer Science
University of Stellenbosch
- Ms I-M Coetzee
Master's student at the former Department of
Consumer Science
University of Stellenbosch

'The scholarship of engagement means connecting the rich resources of the university to our most pressing social, civic and ethical problems... Increasingly, I'm convinced that ultimately the scholarship of engagement also means creating a special climate in which academic and civic cultures communicate more continuously and more creatively with each other, helping to enlarge ... the universe of human discourse and enriching the quality of life for all of us'. (Boyer, 1997: 92)

\section{INTRODUCTION}

Stress amongst academics may be linked to the roles of teaching, research and community engagement and the concomitant pressure that accompanies implementation of these roles within higher education institutions (HEls). One of these aspects, community engagement, coincides with Boyer's scholarship of application (Boyer, 1990). This scholarship is one of the four scholarships of teaching, application (engagement), discovery and integration (Kreber, 2005; Boyer, 1990). The scholarship of engagement entails the application of disciplinary knowledge and skill to address important societal problems (Braxton, 2005). Engagement is often not recognised within the academic environment and thus most neglected by academics when faced with the pressures of multiple roles. In addition, the scholarship of engagement is rarely linked explicitly to the other scholarships (Kreber, 2005). Community engagement has the potential to have benefits on the other roles of academics if there is systematic planning in the process. In this way, academics can develop the various scholarships by specifically developing the nexus between engagement, research (discovery) and teaching.

Community engagement fosters relevance within the context and the geographic environment where a university is situated. HEls should be the vital centres of a nation's work, and science should be of practical service to the nation where there is active respect for the concerns and challenges faced by society. Confidence in HEls grows as academics serve a greater purpose and participate in building a more just society (Mseleku, 2004; Boyer, 1997). Mseleku (2004) believes that South African universities tend to be extensions of European universities thus not rooted in the African experience. Clearly the engagement in communities, as well as producing relevant research, will contribute towards an African identity in higher education.

Benefits to various stakeholders include those to students in teaching and learning role if integrated with the scholarship of application. Educational goals of developing the skills of self management, autonomy and social responsibility are fostered in the process of community engagement as students go out into the community and are involved in solving real problems. This provides them with the opportunity to develop intellectually (critical thinking) and morally (social responsibility). Barnett (2004) noted these skills as be- 
ing essential in the current global era characterised by super-complexity.

The purpose of research is to uncover knowledge that is then used to effect changes. The change relates to empowerment and emancipation from constraining modes of thinking and acting. This must clearly occur among all the stakeholders, such as the lecturers, the students and the community members. According to Kreber (2005), the real question is whether the research made a difference in the lives of those involved. Participatory and democratic structures of community-based research projects are fundamental to how the university fulfils its public mission through research (Berman, 2007). Mutual benefits should accrue to both partners to ensure sustainability. The lecturers and the students need to engage in scholarly practice in communities and in relevant knowledge creation. This process needs to be planned in an integrated manner.

For work done by academics to be considered scholarly, is determined by the degree to which clear goals are established, adequate preparation is done, appropriate methods are used, significant results are produced, an effective presentation of work is created and critical activity is reflected (Glassick et al, 1997). The process needs to be approached systematically and holistically. In the process of integrated scholarly practice in a community engagement project, the post-graduate students' learning is largely selfinitiated in the sense that they are empowered to take an active role in designing their education (research projects) while developing social responsibility and retaining accountability to the community (Kreber, 2005). Lecturers clearly need to facilitate this process and learning in students. Calleson et al (2005) summarise the measure for community-engaged scholarship and these relate to both academics and the community. The community measures relate to communication, assessing and addressing needs to solve identified problems (Calleson et al, 2005). A mutually beneficial partnership between all stakeholders is crucial in the process. This needs to be reflected on and monitored during the course of such an initiative

This article focuses on a community engagement initiative as an integrated scholarly activity applied in a department at a higher education institution. The aim is to describe the process of community engagement within the specialization area of Adult Education. This will be accomplished by describing the community engagement initiative in this particular department; discussing the process of implementation of two research projects by postgraduate students in the rural community in the course of the community engagement initiative and reflecting on the community engagement initiative implemented. It is argued that if Consumer Science academics plan and implement community engagement initiative in a scholarly integrated manner then it could benefit their three roles of research, teaching and community engagement as well as ensure reciprocal benefits to the partners in the interaction process.

\section{THE COMMUNITY ENGAGEMENT INITIATIVE}

The context for the community project was the rural town of Darling. The main source of employment in Darling comes from seasonal work on farms. Darling, $65 \mathrm{~km}$ from Cape Town, is famous for its wild flowers and the Darling Wild Flower show that is held annually. Darling Focus Association is a community-based organisation housed in a modern building situated in the town offering various services, activities and programmes to the community. The association approached the Department of Consumer Science in 1996 with a need for training programmes. A need assessment commissioned by them at that stage had identified the development of entrepreneurial skills as a priority. Thus the community engagement initiative started with the involvement of under-graduate students in 1996 and was expanded to include four postgraduate students from 1999.

In the early phase of the project, the lecturers in Adult Education felt that under-graduate students would benefit from experiential learning within a community setting. It provided an opportunity to apply theoretical inputs in the planning cycle for adult education programmes (needs assessment, programme planning, implementation and evaluation) in a small group in a community. Therefore, after consultation with the community forum, permission was granted and students presented short programmes based on the expressed needs of the group of adult learners from the Darling community. The topics related to food/ nutrition, clothing and housing and included amongst others entrepreneurship. Feedback was provided to the Darling Focus community forum after each semester. The students experienced these sessions as beneficial and the community members returned each year when they heard that students would be presenting programmes.

In 1997 the Department of Consumer Sciences identified a further need for adult education programmes. Botha and Van der Merwe (1999) noted that disadvantaged communities in South Africa, especially those in rural areas, suffer as a result of poverty largely due to unemployment. Although many of these areas hold enormous potential for the development of micro-enterprises and self-employment, this challenge is not always addressed by local initiatives. Consequently the Development and Advancement of Rural Entrepreneurship (DARE) programme was launched in 1999 focussing on training of entrepreneurs through a variety of projects in the rural towns of Darling, Stellenbosch, Montagu and Paarl in the Western Cape Province of South Africa. It was important that these projects addressed needs in a scholarly manner to ensure rigour, accountability and relevance.

DARE programme components included the training of entrepreneurs, the identification of and (where feasible) access to resources, and rendering support to entrepreneurs in establishing small businesses (Botha \& Van der Merwe, 1999). Long-term abstract objectives were to empower a traditionally disadvan- 
taged, resource-weak group and to enhance capacity in the community. The DARE project was awarded funding and five post-graduate students conducted their research projects in the town of Montagu (Perold, 2003) and four in Darling (Bester, 2002; Le Roux, 2003; Coetzee, 2004; Langenhoven, 2004). In this article, two of the post-graduate research projects conducted in the town of Darling within the specialization of Adult Education will be described. These will be described merely as examples of types of projects which could be conducted in a rural setting. Within the aims and scope of this article, the aim is not to describe each of these studies in detail but to illustrate the process and the link to the part played in the larger community engagement initiative.

\section{RESEARCH PROJECTS IN THE RURAL COMMU- NITY OF DARLING}

Postgraduate research projects were conducted during the course of the community engagement initiative and will be discussed briefly in the context of the process of the initiative. Each project investigated a specific aspect of the community and did not stand apart from each other. Each project informed the other as the various postgraduate students immersed themselves in the community and as various challenges emerged. These postgraduate research projects illustrate the scholarship of discovery as well as the academic role of research.

The first study conducted by Bester has already been reported (Botha, et al 2007). This study focussed on developing rural entrepreneurial skills through participatory action research (PAR) in a non-formal adult education programme (Bester, 2002). However, activities at the Darling Focus centre dwindled when the facilitator left (Bester, 2002), a finding confirmed in the study in Montagu by Perold (2003). Apart from individuals who had established their own businesses, only one group of ladies were regularly engaged in sewing related activities at the Centre, but these products were not market related. This observation served as a motivation for the initiation of the second project by Le Roux.

Investigating market related possibilities Darling is a popular tourist destination. The study by Le Roux (2003), therefore, focussed on investigating possibilities for entrepreneurial development in tourism, which was considered relevant within the reality of the growing tourism industry in South Africa. This trend created a need for information concerning tourists' needs regarding products and services that could lead to entrepreneurial development in Darling. A situation analysis was conducted to establish which attractions, products and services are available in Darling. Pertinent and available documents were analysed, structured interviews were conducted with relevant business owners and artists in the region and tourists completed questionnaires.

Compiling a tourist profile was based on four profiles developed by Littrell et al (1994) and served as the basis for the development of two questionnaires. The profile uses various criteria to determine what is important to a tourist when buying products. The four profiles are the active outdoor profile, the historical and park profile, the city profile and the ethnic, cultural and people profile. The questionnaires to establish the needs of the tourists who visited Darling were self-administered. The data obtained related to the demographic details of the respondents, attractions they plan to visit, shopping patterns, preferences regarding the purchase of handwork in order to identify deficiencies that could be addressed by entrepreneurial projects. The results of the situation analysis, profiles and needs of the tourists were compared with what Darling has to offer.

Findings from the situation analysis revealed that Darling offers various attractions including nature and cultural activities. Tourists completed a total of 134 questionnaires. For the majority (53\%) it was their first visit. The main reason for their visit was to see the wild flowers. The profile of the average tourist is related to three of the four categories of Littrell et al (1994) namely the active outdoor profile (64\%), the historical and park profile $(61 \%)$ and the ethnic, cultural and people profile (58\%). The tourists' most important requirements of products are that they should be unique to the area and that they be of high quality, reasonably priced and well designed. It was found that handcraft is the product purchased most.

It was concluded that training and development in Darling should focus on addressing the needs of tourism in the area. The infrastructure available at the Darling Focus Centre could make it an ideal site to incorporate entrepreneurial training connected to tourism. Training programmes to develop and produce the identified products popular amongst tourists (food from the region and handcrafted products) could be provided to prospective entrepreneurs. These products should have a culture or nature theme.

All research results were presented to the Darling Focus management committee to assist with their strategic planning. From then onwards training at the Focus centre focused on making articles for the tourists in town and was presented to community members by under-graduate students and a third master's student (Langenhoven, 2004). Despite these efforts, community members did not take ownership and attendance figures for training sessions remained low. This raised the question of why the community members were not interested in activities presented at the Centre.

A possible reason for programmes coming to an end when the facilitators hand over programmes to the community (Perold, 2003; Bester, 2002) could be that the community's needs and expectations were not being met. The purpose of the forth study by Coetzee (2004) was thus to establish whether this Community Association and the services, activities and programmes presented at the Centre meet the needs and expectations of the Darling community. 
Exploration of needs and expectations of the community A randomised cross-sectional survey design was applied. Data was collected by administering structured interview questionnaires to a random sample of the entire Darling population. This questionnaire measured the community's awareness, viewpoints and expectations of the Community Association and Centre, as well as their needs for activities, services and programmes offered at the Centre.

The questionnaire was completed by 357 respondents. The majority of respondents $(89 \%)$ had not participated in non-formal education during the previous five years. Of those who had participated, the majority of courses were work-related. Just more than half of the respondents were aware of the Darling Focus Centre and the social service and training activities offered at the Centre, but $44 \%$ had never visited the Centre. Of those respondents who were aware of the Centre, $66 \%$ had never participated and only $5 \%$ had participated at all.

The community saw the Association and social services provided at the centre as synonymous. It was furthermore associated with the provision of training activities and job creation, as well as with the provision of community activities and addressing community issues. More females perceived activities and care for children, as well as social work as positive, while more males perceived training, job creation and job seeking as positive.

Respondents viewed training activities as an important shortcoming in the community and accordingly indicated a need for this, more specifically computerand job training. Gender, age, race, level of education and employment status had statistically significant relationships related to preferred training activities. Computer training preference was noted across both sexes, across the different age groups, amongst black and coloured respondents and by housewives and students. Job training was preferred most by $16-$ to 30-year-olds, those with tertiary qualifications, those unable to work and the white racial group.

For respondents 65 years of age and older, needlework was the preferred activity. Those with no education also preferred needlework and only $8 \%$ of those respondents felt that they needed adult basic education and training (Abet). The unemployed and those looking for work preferred computer training, job training, needlework and technical training.

Associations should take note of the problems of a community, as well as of their preferences for activities and their needs for courses. It should attempt to provide for these needs and preferences in order to improve the sustainability of the activities offered by the association. Participation could also contribute to increased sustainability and ensure that residents, who need activities and services the most (the poorest of the poor), are able to reap the benefits of activities and services offered.

\section{REFLECTION ON THE COMMUNITY ENGAGE- MENT INITIATIVE IMPLEMENTED}

Two projects have been discussed and this section documents the lecturer/supervisors' reflections on the community engagement initiative. The initiatives reported on in this article provide an example of mutual benefits to the university and the community. The various stakeholders include the students, the community, and those in academe (lecturers and colleagues in related disciplines).

The benefits of the integration in these community engagement initiatives to students and their process of learning were identified. As noted by Kreber (2005), the students' learning was largely self-initiated as they played an active role in designing their research project whilst being involved in the community. Thus social responsibility was developed and accountability to the community was retained. Development of rigorous scholarship within the community setting at the post-graduate level ensured quality due to the facilitation and review process with the supervisor and co-supervisor and accountability to the community where research was conducted. The use of appropriate research methods such as action research or participatory research is appropriate for community projects as community participation is one of the principles of community development. This was applied by one of the students and has been reported in detail in Botha et al (2007). Engagement which does not only result in a postgraduate qualification but which serves to benefit the community is essential. In this initiative there was long term engagement over a seven year period. The Department of Consumer Science provided continuity when an individual postgraduate student withdrew from the project as other post-graduate students continued with involvement in the community. Concurrently, under-graduate students were involved in short course presentations in their practical course work component for the adult education module.

The Darling Focus coordinator from the community reported that the Darling Focus Association took notice of the research recommendations and had arranged for accredited training programmes of the Department of Labour to be presented at the Centre They have also taken the initiative to apply for funding for the construction of a swimming pool behind the Darling Focus Centre and plans have been drawn up and submitted. There are also plans for a radio station and an amphitheatre in the town. This indicates evidence of the community organising themselves and taking responsibility for their own development, one of the principles of community development (Swanepoel, 1997).

One of the requirements of scholarship is rigorous research, communication and validation (Smith, 2004). Identification of the public benefits of engagement could encourage broader public interest in the work being done (McGrath, 2006). This coincides with the scholarship of integration of Boyer (1990) regarding dissemination to the community (Darling) and well 


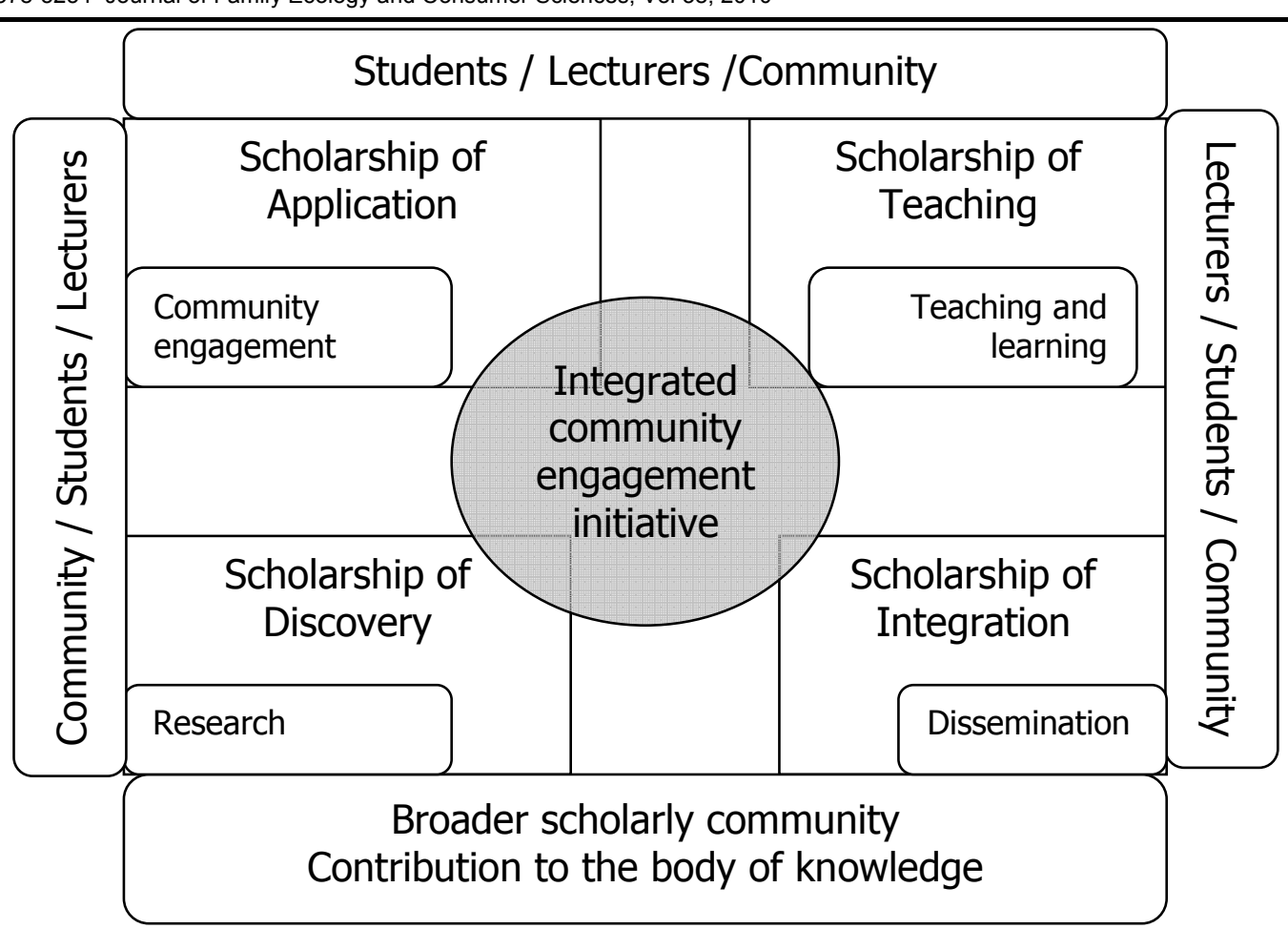

\section{FIGURE 1: INTEGRATED COMMUNITY ENGAGEMENT INITIATIVE}

as the broader scholarly community. One publication has already emanated from this initiative (Botha et al, 2007), as well as six papers presented at international conferences. By conducting rigorous research while engaging in the community, the relevance of the university within its context is enhanced which increases accountability. It also makes a contribution to the body of knowledge.

The following diagramme indicates the integrated approach followed in this community engagement initiative (see Figure 1).

The stakeholders in the community engagement initiative are the broader scholarly community, the community, lecturers and students. Various activities are undertaken in the process and because it is an academically driven process, the aim is to extend the body of knowledge which will benefit the scholarly community as well as have an impact on the community which the university serves. The lecturers need to plan and implement an integrated approach where the three roles of academics are accomplished (teaching, research and community engagement) but this must be done in a scholarly manner in line with the four scholarships (Boyer, 1997:92). Dissemination is important and stakeholders (students, Darling's community as well as the broader scholarly community) are informed of the research outcomes. Following an integrated approach will ensure reciprocal benefits albeit varying in degrees to the various stakeholders. In following this integrated approach, appropriate processes should be put in place to ensure relevance, accountability and reciprocal benefits. All stakeholders are beneficiaries in the process and this should be acknowledged and facilitated.
Various aspects need to be borne in mind to ensure an integrated approach to community engagement:

- Teaching and learning related to adult education and community development principles

- Planned activities

- Appropriate research methods

- Quality

- Ethical issues

- Focus on sustainability

- Reciprocal benefits

- Dissemination both to rural and academic community

\section{CONCLUSION}

In response to the challenges facing those with limited resources, especially in rural areas in South Africa, the broad motivation for this community initiative was to improve the lives of individuals and to empower a traditionally disadvantaged and resourceweak group through capacity building in the community. A process of scholarly engagement was implemented over a period of time (seven years) with continuity and sequential assessing and addressing of identified needs. The two examples of studies reported focus on assessing the needs of this Darling community in order to identify issues relevant to them for their development. Community engagement, in line with scholarly principles, could help to integrate the various scholarships on the part of academics and of students in preparation for professional practice. In the cases mentioned, the students applied theoretical adult education and community development principles in a scholarly manner. They learned 
skills of discovery, and quality and rigour was built into the scientific research procedures applied in this community setting. Various research methods were applied which were relevant to the setting of the research. It was thus responsive to the needs of the target community. Students learned the importance of engagement in the community and experientially learned respect, accountability and relevance.

Further research could focus on evaluation of the nature of the benefits to the various stakeholders in the community engagement initiatives. The conceptual framework developed in this article could be tested during the course of planning and implementing a community engagement initiative.

If an integrated approach is planned and implemented by academics it can help to improve relevance and accountability in the context where the university is situated. This could contribute towards creating what Boyer (1997:92) refers to as a "special climate" for relevance for the community where the university is situated. This approach would help academics reflect upon and ensure the reciprocal benefits on the various stakeholders. In building in a scholarly approach to performing various roles of academics, they can increase their efficacy, streamline activities and also contribute to the body of knowledge within the scholarly community.

\section{REFERENCES}

BARNETT, R. 2004. Learning for an unknown future. Higher Education Research and Development 23 (3):247-261.

BERMAN, K. 2007. Shifting the paradigm: The need for assessment criteria for community engaged research in the visual arts. Unpublished paper: "Postgraduate supervision: The state of the art and the artists". April 2007, Stellenbosch. University of Stellenbosch.

BESTER, A. 2002. A participatory action research approach to programme evaluation in a rural society. Unpublished master's thesis. Stellenbosch. University of Stellenbosch.

BOTHA, MJ \& VAN DER MERWE, ME. 1999. DAREprogramme: Proposal for funding. Stellenbosch. University of Stellenbosch.

BOTHA, MJ, VAN DER MERWE, ME, BESTER, A \& ALBERTYN, RM. 2007. Entrepreneurial skill development: Participatory action research approach in a rural community. Journal of Family Ecology and Consumer Science 35: 9-19.

BOYER, EL. 1990. Scholarship reconsidered: Priorities of the professoriate. Princeton, NJ. Carnegie Foundation for the Advancement of Teaching.

BOYER, EL. 1997. Ernest L Boyer: Selected speeches 1979-1995. Princeton, NJ. Carnegie Foundation for the Advancement of Teaching.

BRAXTON, JM. 2005. Reflections on a scholarship of practice. Review of Higher Education 28(2):285-293.

CALLESON, DC, JORDAN, C \& SEIFER, S. 2005. Community engaged scholarship: Is faculty work in communities a true academic enterprise? Academic Medicine 80(4):317-321.

COETZEE, I-M. 2004. The assessment of a rural community's needs and expectations regarding a community association. Unpublished master's thesis. Stellenbosch. University of Stellenbosch.

GLASSICK, CM, HUBER, MT \& MAERHOFF, G. 1997. Scholarship assessed: Evaluation of the Professoriate. San Francisco. Jossey-Bass Publishers.

KREBER, C. 2005. Charting a critical course on the scholarship of university teaching movement. Studies in Higher Education 30(4):389-405.

LANGENHOVEN, MC. 2004. ' $n$ Intervensieprogram vir bevordering van inkomstegenerering in 'n landelike gemeenskapssentrum. Unpublished master's thesis. Stellenbosch. University of Stellenbosch.

LE ROUX, A. 2003. Ondersoek na moontlikhede vir entrepreneuriese ontwikkeling in ' $n$ landelike toerisme-area. Unpublished master's thesis. Stellenbosch. University of Stellenbosch.

LITTRELL, MA, BAIZERMAN, S, KEAN, R, GAHRING, S, NIEMEYER, S, REILLY, R \& STOUT, J. 1994. Souvenirs and tourism styles. Journal of Travel Research 33(1):3-12.

MSELEKU, T. 2004. African scholarship: Some challenges facing intellectuals in South African higher education institutions. Ingede. Journal of African Scholarship 1(2):1-3.

McGRATH, DM. 2006. The scholarship of application. Journal of Extension 44(2):1-11.

PEROLD, J. 2003. Entrepreneurial development through non-formal adult education and skills training in a rural community. Unpublished master's thesis. Stellenbosch. University of Stellenbosch.

SMITH, KL. 2004. Scholarship: Shout about it. Journal of Extension 42(5):1-4.

SWANEPOEL, H. 1997. Community Development. Putting plans into action (3rd ed.). Cape Town. Juta 